\title{
VORM VAN DE ACCOUNTANTSVERKLARING BIJ CONTROLE OP DE NALEVING VAN KARTEL- OVEREENKOMSTEN
}

\author{
door Drs J. de Jong
}

In het kader van een contrôleleer-examen is de volgende vraag naar voren gekomen: .,Moet bij een contrôle op de naleving van kartelvoorschriften de verklaring van de accountant in het algemeen op positieve of op negatieve wijze worden geformuleerd, d.w.z. moet de verklaring luiden dat de voorschriften zijn nageleefd, of moet de accountant verklaren dat hem van overtreding van de voorschriften niet is gebleken?".

Vooropgesteld zij dat het theoretisch schema voor de kartel-contrôle luidt: een door de aard der contrôlepunten veelal op volledig uitlopende contrôle van de kartelbepalingen, gebaseerd op een volkomen contrôle van de jaarrekening.

Vergelijkt men het doel van een verklaring, afgegeven op grond van een kartelcontrôle met het doel van een verklaring bij een jaarrekening, dan is er een duidelijk verschil: de derden-belanghebbenden wensen in het geval van een jaarrekening zekerheid, dat het gegeven beeld van de finantiële positie en van de behaalde resultaten een aanvaardbaar uitgangspunt is voor het oordeel dat zij zich omtrent de onderneming willen vormen. Het .verkeer" verwacht van dit beeld geen absolute juistheid.

Bij de (beperkte) kring dergenen die belang hebben bij de naleving van kartelvoorschriften ligt de zaak anders. $Z_{i j}$ behoeven eigenlijk een volkomen zekerheid want door elke overtreding worden zij geschaad. Daarom, èn omdat zich voor de verklaringen betreffende deze contrôles geen norm ontwikkeld heeft zoals voor de contrôle van de jaarrekening, worden hier aan de accountantsverklaring grotere duidelijkheidseisen gesteld; zij moet veel nauwkeuriger dan in het geval van een certificaat bij een jaarrekening aangeven welke haar betekenis is voor belanghebbenden.

De negatieve verklaring geeft beter weer dan de positieve dat aan het onderzoek gebreken inhaerent zijn; zij geeft aan dat aan de accountant geen overtredingen zijn gebleken doch waarschuwt in dezelfde formulering voor de mogelijkheid dat buiten het met zijn contrôle bereikbare terrein iets gebeurd kan zijn. Het geven van een positieve verktaring, met stilzwijgend beroep op het z.g. axiomatisch voorbehoud, is hier vrijwel nooit toelaatbaar, omdat het onderzoek zich veelal mede moet richten op punten, waarvan de Justherd door onderzoek van de administratie meestal niet is vast te stellen.

Ook een op hef vinden van ontduikingen toegespitste contrôle neemt de mogelijkheid tot ontduiking veelal dus niet geheel weg. Een positieve verklaring wekt derhalve een te groot vertrouwen; het is zeris warschijnlljk dat de zeer deskundigen ult de beperkte kring daarvan met enige geringschatting kennis nemen.

Vóór de aanvaarding van een opdracht tot kartelcontrôle dient de accountant dan ook te onderzoeken of de kartelbepalingen een doelmatige contrôle mogelijk maken. Alleen hij kan in een bepaald geval beoordelen of de noodzakelijke onvolkomenheden een doeltreffende 
contrôle op de naleving in de weg staan d.w.z. of hij in staat is ontduiking aan het licht te brengen zonder dat de kosten van het onderzoek het nut van de kartelovereenkomst illusoir maken.

Het is wenselijk, dat de accountant in daarvoor in aanmerking komende gevallen reeds aan de aanvaarding van zijn opdracht de mededeling verbindt dat zijn contrôle niet zodanig kan zijn, dat alle ontduikingen aan het licht komen.

Het vorenstaande - dat geldt ongeacht het aan de overeenkomst ten grondslag liggende object (prijzen, quoten, gebied, condities, klantenbescherming, resultaten-pooling, etc.) - heeft betrekking op kartelcontrôles, die het theoretisch ideaal-schema benaderen. In de praktijk komen daarnaast enkele schakeringen van het optreden als kartel-accountant voor:

a. de accountant treedt alleen op indien tegen één der leden een klacht is ingediend.

Uiteraard zal zijn verklaring alsdan uitsluitend zijn bevindingen bij het onderzoek van de aanhangig gemaakte concrete overtreding weergeven;

b. de accountant treedt op indien tegen één der leden een klacht is ingediend en daarenboven neemt hij steekproeven in de administraties der aangeslotenen ter opsporing van overtredingen.

Dit functionneren heeft zin omdat - voor opgesteld dat de accountant van de doelmatigheid van steekproeven overtuigd is - dit contrōlemiddel de mogelijkheid opent systematische afwijkingen, ingeslopen door onkunde of door bewuste of onbewuste onjuiste interpretatie van de bepalingen, op het spoor te komen. De beperktheid van de functie moet dan echter voor elk der belanghebbenden vaststaan en de verklaring moet daarop gericht $z$ ijn.

Helaas komt het in de praktijk nog wel voor dat deze functie wordt aangezien voor - en aangediend als! - een volwaardige kartelcontrôle. De bewoordingen van de verklaring mogen geen enkele twijfel openlaten omtrent hetgeen met deze contrôle bereikbaar is en omtrent hetgeen bereikt is. De negatieve verklaring mag niet worden gebruikt om een onvolkomen contrōle te camoufleren. 